\title{
ANALISIS ELEMEN HINGGA NONLINIER BALOK GESER BETON MEMADAT MANDIRI DAN BETON MUTU TINGGI
}

\author{
Mahmud Kori Effendi ${ }^{1)}$, Novi Rahmayanti ${ }^{2)}$ \\ ${ }^{1,2)}$ Fakultas Teknik Sipil dan Perencanaan, Universitas Islam Indonesia, Yogyakarta \\ Email: kori.effendi@uii.ac.id ${ }^{1)}$, novi.rahmayanti@uii.ac.id ${ }^{2)}$
}

DOI: http://dx.doi.org/10.29103/tj.v11i2.518

(Received: April 2021 / Revised: July 2021 / Accepted: August 2021)

\begin{abstract}
Abstrak
Indonesia merupakan negara yang rentan terhadap bencana gempa bumi. Banyak rumah atau gedung di Indonesia dibangun dengan menggunakan material beton bertulang. Kerusakan geser pada elemen beton bertulang tersebut sangat berbahaya, hal ini dikarenakan kerusakan ini terjadi secara tiba-tiba dan biasanya terjadi secara eksplosif. Analisis nonlinier elemen hingga tiga dimensi balok beton memadat mandiri dan beton mutu tinggi dengan pemadatan mekanis dilakukan dengan software MSC Marc/Mentat. Baja dimodelkan dengan tertanam di beton. Kriteria kegagalan Linier Mohr-Coulomb digunakan untuk beton dan Von Mises untuk baja tulangan. Hasil kurva hubungan beban-lendutan untuk kedua balok beton memadat mandiri dan beton mutu tinggi pemadatan mekanis hampir sama dengan hasil kurva eksperimen di daerah elastic, namun setelah melewati fase elastik, kurva analisis berbeda sedikit dengan kurva eksperimen. Hasil analisis teoritis kekuatan beton hampir sama dengan hasil analisis elemen hingga balok beton tanpa tulangan. Hasil analisis kontak juga memperlihatkan terjadi kontak dan perlepasan pada bidang kontak baja tumpuan beban dan tumpuan balok dengan beton.
\end{abstract}

Kata kunci: beton memadat mandiri, mutu tinggi, elemen hingga, MSC Marc/Mentat

\begin{abstract}
Indonesia is a country that is prone to earthquakes. Many houses or buildings in Indonesia are built using reinforced concrete material. Shear damage to reinforced concrete elements is very dangerous, because this damage occurs suddenly and usually occurs explosively. The nonlinear three-dimensional finite element analysis of selfcompacting concrete beam and high strength concrete beam by mechanical compaction were carried out using the MSC Marc/Mentat software. Steel is modeled by being embedded in concrete. The Mohr-Coulomb Linear failure criterion is used for concrete and Von Mises for reinforcing steel. The results of the load- deflection curves for both self-compacting and mechanical compaction high-strength concrete beams are almost the same as those of the experimental curves in the elastic area, after elasticity, the analysis curve differs slightly from the experimental curve. The results of the theoretical analysis of the strength of the concrete are almost the same as the results of the analysis of the finite element concrete beams without reinforcement. The results of the contact analysis also showed that there was contact and detachment in the contact area of the load bearing steel and the beam support with the concrete.
\end{abstract}

Keywords: self-compacting concrete, high strength, finite element, MSC Marc/Mentat 


\section{Latar Belakang}

Indonesia merupakan negara yang rentan terhadap bencana gempa bumi, hal ini dikarenakan Indonesia berada di wilayah ring of fire hal yang membahayakan adalah bencana gempa bumi tidak bisa diprediksi kapan waktu terjadinya dan berapa besar kekuatan gempanya. Banyak rumah atau gedung di Indonesia dibangun dengan menggunakan material beton bertulang. Rumah maupun Gedung tersebut harus kuat dalam menahan beban gempa, sehingga harus diperhitungkan dengan matang tentang penggunaan beton dan baja tulangan.

Baja tulangan berfungsi untuk memperkuat beton apabila terjadi retak pada elemen struktur karena beton sangat lemah dalam menahan gaya tarik, sehingga kelemahan ini diisi oleh baja tulangan. Umumnya baja tulangan digunakan untuk menahan dari gaya geser, momen lentur dan momen torsi akibat beban luar pada elemen bangunan seperti balok, kolom dan fondasi. Kerusakan geser pada elemen beton bertulang tersebut sangat berbahaya, hal ini dikarenakan kerusakan ini terjadi secara tiba-tiba dengan sedikit ataupun tanpa adanya peringatan dan biasanya terjadi secara eksplosif (Tambusay, Suryanto and Suprobo, 2018).

Gaya geser terbesar terjadi di dekat tumpuan, dengan kata lain terjadi di dekat joint/pertemuan antara balok dan kolom. Penelitian mengenai sengkang sebagai tulangan yang berfungsi menahan gaya geser sudah diteliti, diantaranya penempatan sengkang yang mengikuti truss analogy kegagalan geser yang bersudut 45 derajad sampai dengan permodelan strut and tie (Zhou, Liu and He, 2018). Umumnya penulangan yang ada di daerah tersebut sangat rapat, sehingga terkadang menyebabkan beton sulit untuk menjangkau celah antar tulangan. Beton yang bisanya digunakan untuk konstruksi bangunan adalah beton normal. Agar struktur mampu menahan beban yang bekerja perlu menggunakan beton mutu tinggi. Untuk membuat beton yang bermutu tinggi maka akan menghasilkan rendahnya workability sehingga beton menjadi sulit untuk dituang ke dalam bekisting. Apabila hal tersebut terjadi maka akan membuat beton keropos dan mengurangi kekuatan strukturnya akibat adanya pengurangan luas penampang beton dan mengurangi kinerja dari baja tulangan akibat minimnya interlocking antara beton dan baja tulangan, oleh sebab itu, dibutuhkanlah beton yang mampu memadat dengan sendirinya agar beton mampu menyelimuti tulangan dengan baik dan mampu meminimalisir terjadinya segregasi sehingga beton memadat mandiri/Self Compacting Concrete (SCC) mampu meningkatkan kapasitas beton bertulang dibandingkan dengan beton yang dipadatkan secara mekanis (Shatarat, Mahmoud and Katkhuda, 2018).

Perkembangan teknologi beton juga sangat berkembang dengan cepat. Salah satu jenis beton terbaru adalah beton memadat mandiri / Self Compacting Concrete (SCC)(Okamura and Ouchi, 2003). Beton ini mempunyai sifat yang khusus yaitu dapat mengalir sendiri di dalam cetakan elemen struktur bangunan dengan berat sendirinya tanpa melakukan proses pemadatan dengan getaran, mampu mengalir pada struktur bangunan yang memiliki jarak tulangan yang cukup rapat tanpa terjadinya segregasi dan tetap menjamin homogenitas pada beton (Ahmad, Umar and Masood, 2017). Selain itu beton SCC mampu menghasilkan beton yang bermutu tinggi sehingga dapat lebih besar menahan beban.

Kekuatan geser balok beton bertulang dengan beton memadat mandiri dan beton mutu tinggi belum banyak diteliti di Indonesia. Kekuatan geser pada peraturan perencanaan di Indonesia masih menggunakan beton normal (SNI 2847, 
2013). Pengujian balok yang rusak lentur hingga geser membutuhkan biaya yang mahal. Penelitian ini bertujuan menvalidasi penggunaan analisis elemen hingga untuk mengamati perilaku geser balok beton memadat mandiri dan balok beton mutu tinggi.

\section{Metode Penelitian}

\subsection{Data Eksperimen}

Analisis balok bertulang dengan beton memadat mandiri dan beton mutu tinggi diawali dengan penyediaan data eksperimen. Beton memadat mandiri merupakan beton yang mampu memadat dengan sendirinya (Self Compacting Concrete) sedangkan beton mutu tinggi memerlukan pemadatan mekanik. Balok beton bertulang eksperimental tersebut diambil dari penelitian Harkouss (Harkouss and Hamad, 2015). Balok uji berupa balok beton memadat mandiri dan beton mutu tinggi pemadatan mekanis seperti pada Tabel 1. Sifat mekanik bahan benda uji dapat dilihat pada Tabel 2. Balok mempunyai bentuk penampang persegi dengan lebar $200 \mathrm{~mm}$ dan tinggi $300 \mathrm{~mm}$ dengan tulangan longitudinal D20 untuk sisi bawah dan P12 untuk sisi atas dan juga tulangan transversal P8 yang dipasang dengan jarak $300 \mathrm{~mm}$, seperti ditunjukkan pada Gambar 1. Balok beton bertulang diuji menggunakan mesin Material Testing System (MTS) servo hidraulik dengan aktuator yang memiliki kapasitas $1.000 \mathrm{kN}$. Balok mempunyai tumpuan sendi-rol dengan panjang as $1800 \mathrm{~mm}$ dengan dua titik pembebanan. Pengaturan uji eksperimen balok beton bertulang ditunjukkan pada Gambar 2 .

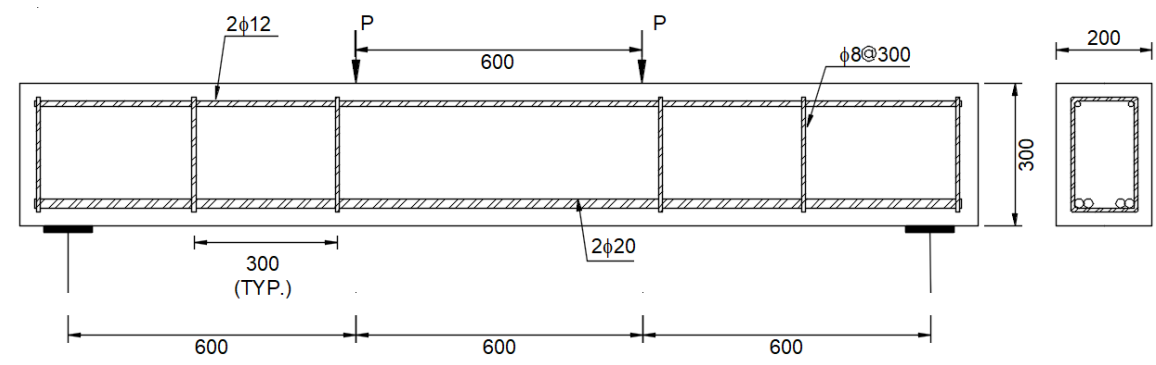

Gambar 1 Layout penulangan tulangan geser (Harkouss and Hamad, 2015)

Pemberian beban melalui aktuator didistribusikan melalui balok perata beban ke dua buah pelat beban berjarak $600 \mathrm{~mm}$ yang kemudian disebut sebagai beban $P$.

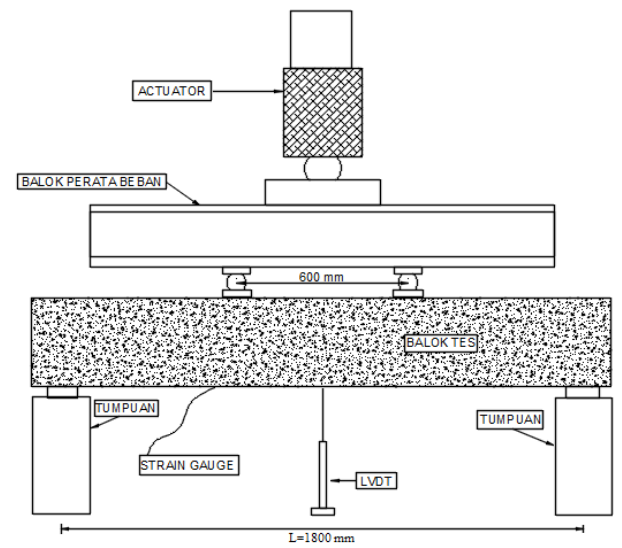

Gambar 2 Pengaturan balok eksperimen 
Beban diterapkan secara bertahap sebesar $10 \mathrm{kN}$ sampai mencapai keruntuhan balok. Gambar 2 menunjukkan posisi Linear variable displacement transducers (LVDT), posisi pembebanan dan tumpuan.

Tabel 1 Notasi benda uji

\begin{tabular}{ccc}
\hline Notasi Balok & Adukan Beton & Jumlah Benda Uji \\
\hline SCC-SH-B1 & Beton Memadat Mandiri & 1 \\
\hline SCC-SH-B2 & Beton Memadat Mandiri & 1 \\
\hline VC-SH-B1 & Beton Mutu Tinggi Pemadatan Mekanis & 1 \\
\hline VC-SH-B2 & Beton Mutu Tinggi Pemadatan Mekanis & 1 \\
\hline
\end{tabular}

Penelitian ini menggunakan 2 buah balok beton yang memadat mandiri (SCCSH-B1 dan SCC-SH-B2) serta 2 buah balok beton mutu tinggi dengan pemadatan mekanis (VC-SH-B1 dan VC-SH-B2) seperti yang terlihat di Tabel 1. Adapun sifat mekanik balok eksperimen pada Tabel 2 diperoleh dari hasil pengujian laboratorium.

Tabel 2 Sifat mekanik balok eksperimen

\begin{tabular}{|c|c|c|}
\hline Bahan & \multirow{2}{*}{\multicolumn{2}{|c|}{$\begin{array}{c}\text { Properti Bahan } \\
\text { Memadat Mandiri }\end{array}$}} \\
\hline \multirow{8}{*}{ Beton } & & \\
\hline & Modulus Elastisitas, $E$ & $35133 \mathrm{MPa}$ \\
\hline & Poisson ratio, $v$ & 0,3 \\
\hline & Kuat Tarik beton, $f_{t}$ & $4,3 \mathrm{MPa}$ \\
\hline & Mutu ] & \\
\hline & Modulus Elastisitas, $E$ & $33103 \mathrm{MPa}$ \\
\hline & Poisson ratio, $v$ & 0,3 \\
\hline & Kuat Tarik beton, $f_{t}$ & 3,8 \\
\hline \multirow{15}{*}{ Tulangan Baja } & \multicolumn{2}{|c|}{ Lentur Bawah $2 \phi 20$} \\
\hline & Modulus Elastisitas Baja, $\mathrm{E}_{\mathrm{s}}$ & $200000 \mathrm{MPa}$ \\
\hline & Poisson ratio, $v$ & 0,3 \\
\hline & Tegangan Leleh Baja Tulangan, $f_{y}$ & $632 \mathrm{MPa}$ \\
\hline & Kuat Ultimit, $f_{u}$ & $743 \mathrm{MPa}$ \\
\hline & \multicolumn{2}{|c|}{ Lentur Atas $2 \phi 12$} \\
\hline & Modulus Elastisitas Baja, $\mathrm{E}_{\mathrm{s}}$ & $290000 \mathrm{MPa}$ \\
\hline & Poisson ratio, $v$ & 0,3 \\
\hline & Tegangan Leleh Baja Tulangan, $f_{y}$ & $557 \mathrm{MPa}$ \\
\hline & Kuat Ultimit, $f_{u}$ & $667 \mathrm{MPa}$ \\
\hline & \multicolumn{2}{|c|}{ Geser $\phi 8$} \\
\hline & Modulus Elastisitas Baja, $\mathrm{E}_{\mathrm{s}}$ & $220000 \mathrm{MPa}$ \\
\hline & Poisson ratio, $v$ & 0,3 \\
\hline & Tegangan Leleh Baja Tulangan, $f_{y}$ & $569 \mathrm{MPa}$ \\
\hline & Kuat Ultimit, $f_{u}$ & $661 \mathrm{MPa}$ \\
\hline \multirow{2}{*}{$\begin{array}{c}\text { Pelat } \\
\text { Tumpuan }\end{array}$} & Modulus Elastisitas Baja, $\mathrm{E}_{\mathrm{s}}$ & $199948 \mathrm{MPa}$ \\
\hline & Poisson ratio, $v$ & 0,3 \\
\hline
\end{tabular}

\subsection{Model Konstitutif untuk Material Beton dan Baja}

Kriteria kegagalan beton menggunakan Linear Mohr-Coulomb dengan kinematic hardening untuk aliran plastisitas. Material beton memadat mandiri dan beton mutu tinggi dengan pemadatan mekanis bersifat isotropik dengan faktor retensi geser/shear retention factor diambil 0,03 dan 0,09. Model tegangan 
regangan dapat dilihat pada Gambar 3 (Kachlakev et al., 2001). Model ini juga digunakan untuk analisis lentur balok beton mutu tinggi (Effendi, 2020). Kekuatan beton sebesar 62,4 MPa dan 57,9 MPa untuk beton memadat mandiri dan beton mutu tinggi pemadatan mekanis, berturut-turut (Harkouss and Hamad, 2015). Regangan beton hancur diambil sebesar 0,003. Nilai rasio Poisson adalah 0,3.

Tegangan retak beton dalam kondisi tarik mempengaruhi perilaku nonlinier balok beton bertulang. Gambar 4 menunjukkan model beton pada kondisi tarik. Model material elastic-brittle diasumsikan pada kondisi tarik. Pada model ini kekuatan beton turun menjadi nol setelah tegangan tarik tercapai, seperti pada Gambar 4 ditunjukkan dengan garis tebal.



Gambar 3 Model beton pada kondisi tekan (Kachlakev et al., 2001)

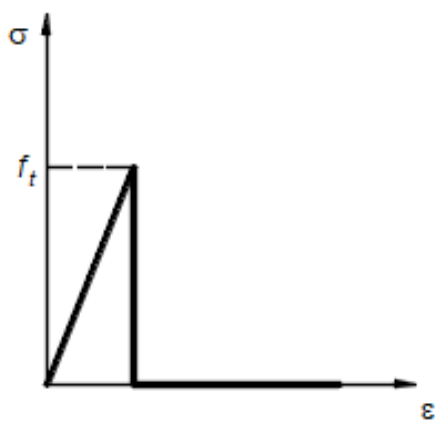

Gambar 4 Model beton kondisi tarik getas

Baja tulangan dimodelkan dengan menggunakan elemen truss tipe 9 MSC Marc/Mentat (Marc, 2012). Sifat material baja dimodelkan dengan bilinier seperti pada Gambar 5. Kriteria leleh baja tulangan menggunakan kriteria Von Mises.

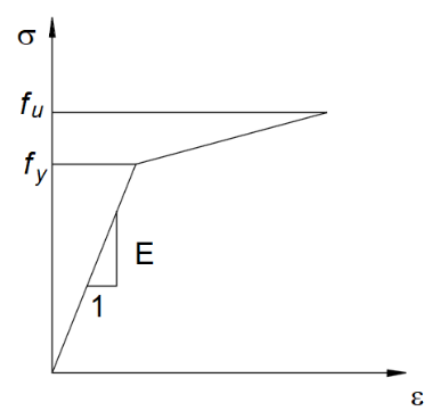

Gambar 5 Model tulangan

Analisis Elemen Hingga Nonlinier Balok Geser Beton Memadat Mandiri dan Beton Mutu Tinggi - Mahmud Kori Effendi, Novi Rahmayanti 


\subsection{Verifikasi dengan Analisis Elemen Hingga}

Analisis balok menggunakan perangkat lunak MSC Marc/Mentat (Marc, 2010). MSC Marc digunakan untuk proses memecahkan masalah struktur statik dan dinamik yang kompleks dengan pendekatan material atau geometrik linier atau nonlinier. Perbedaannya dengan perangkat lunak yang lain adalah kemampuan untuk memecahkan masalah kontak antar elemen dan kemampuan automesh dan remeshing. MSC Mentat adalah antar muka grafis pada MSC Marc untuk membuat model elemen hingga, pemberian beban, pendefinisian kondisi batas, dan kondisi beban. Meshing beton pada analisis elemen hingga balok uji seperti pada Gambar 6 , dilakukan dengan skala penuh. Kondisi tumpuan dan pembebanan dapat dilihat pada Gambar 7. Balok menumpu pada pelat tumpuan. Pada bagian tengah nodal pelat tumpuan diatur menahan pergerakan ke arah $x, y$ dan $z$ dan juga menahan rotasi $x$ dan $z$ tetapi bebas terhadap rotasi arah $y$. Tumpuan balok menggunakan pelat baja ukuran $100 \times 25 \mathrm{~mm}$. Elemen balok dan pelat menggunakan elemen solid persegi panjang. Analisis kontak diberikan pada elemen balok dan elemen pelat dengan menggunakan pendekatan touching contact. Untuk memodelkan lentur murni maka dua beban berjarak $600 \mathrm{~mm}$ ditempatkan simetri terhadap tengah bentang balok. Pemberian beban menggunakan pendekatan kontrol lendutan/ displacement control. Meshing pada tulangan sengkang dan tulangan lentur dapat dilihat pada Gambar 8.

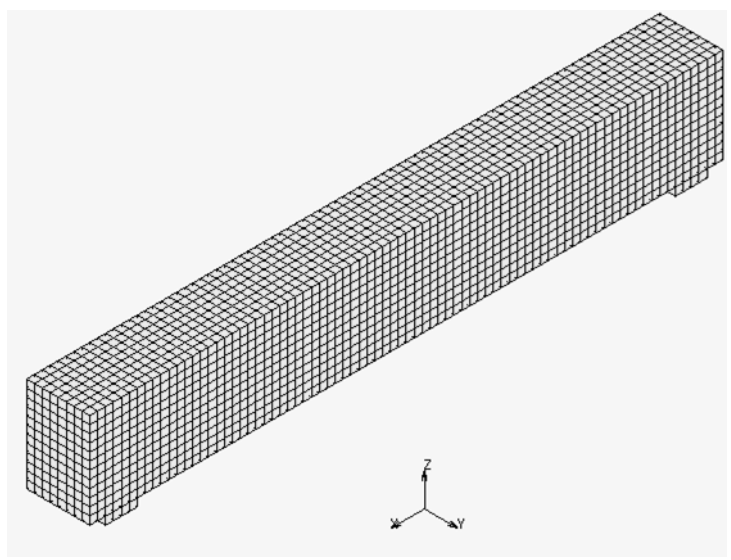

Gambar 6 Meshing beton

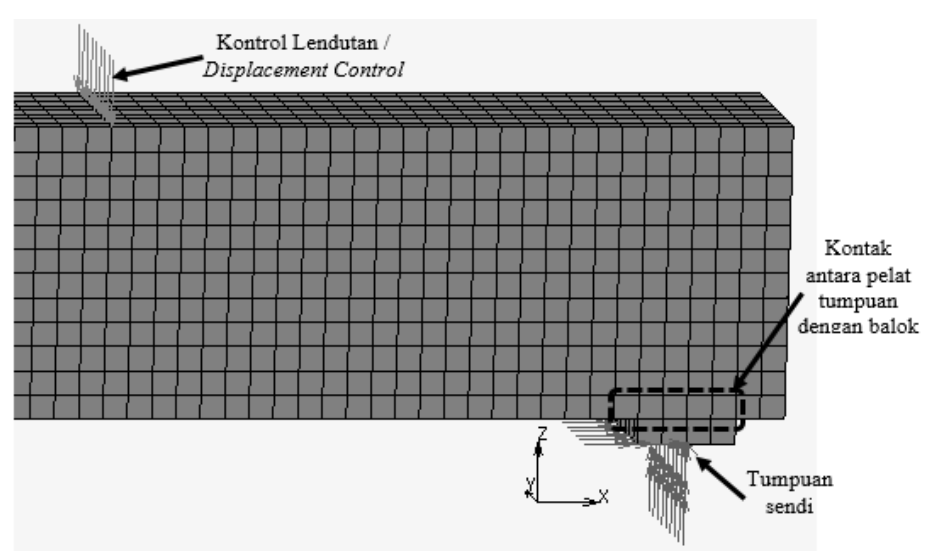

Gambar 7 Kondisi batas tumpuan dan pembebanan 


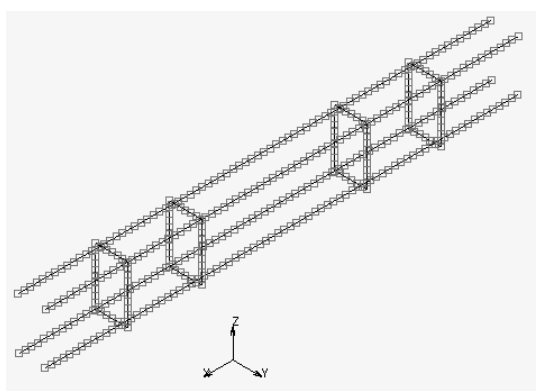

Gambar 8 Model beton kondisi tarik getas

Salah satu pemodelan interaksi tulangan baja dan beton adalah menggunakan model tertanam/ embedded model seperti pada Gambar 9. Model ini tidak berbagi nodal antara nodal beton dan nodal tulangan baja.

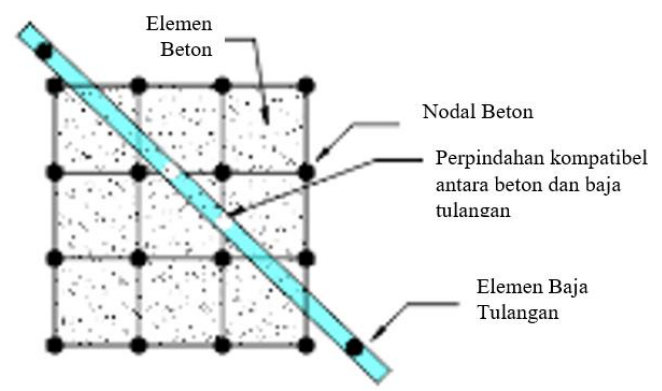

Gambar 9 Pemodelan tertanam/embedded (Tavárez, 2001)

\subsection{Kekuatan Geser SNI 2847, 2019}

Kekuatan geser nominal $\left(\phi V_{n}\right)$ sebagai jumlah dari kekuatan yang diberikan oleh beton dan tulangan baja menurut persamaan: (SNI 2847, 2019)

$$
\phi V_{n}=\phi\left(V_{c}+V_{s}\right)
$$

\section{Keterangan}

$V_{n} \quad=$ Kekuatan geser nominal $(\mathrm{kN})$;

$V_{c} \quad=$ Kekuatan geser beton $(\mathrm{kN})$

$V_{c} \quad=$ Kekuatan geser akibat tulangan geser $(\mathrm{kN})$

$\phi \quad=$ Faktor reduksi kekuatan $(0,75)$

Untuk komponen-komponen struktur yang menahan geser dan lentur saja dihitung dengan persamaan 1-3 (SNI 2847, 2019). Persamaan tersebut memberikan kapasitas kemampuan beton (tanpa penulangan geser) untuk menahan gaya geser adalah $V_{c}$

$$
V_{c}=0,17 \lambda \sqrt{f_{c}^{\prime}} b d
$$

\section{Keterangan}

Untuk beton normal, $\lambda=1,0$.

$V_{c} \quad=$ kuat geser beton $(\mathrm{N})$

$f_{c}^{\prime}=$ kuat tekan beton $\left(\mathrm{N} / \mathrm{mm}^{2}\right)$

$b \quad=$ lebar efektif penampang balok $(\mathrm{mm})$

$d \quad=$ Tinggi efektif penampang balok beton bertulang $(\mathrm{mm})$ 
Untuk tulangan geser, Vs dapat dihitung menurut persamaan 11-15 (SNI 2847, 2019), di mana:

$$
V_{s}=\frac{A_{v} f_{y} d}{s}
$$

Keterangan

$V_{s} \quad$ = Gaya geser nominal yang disediakan oleh tulangan sengkang $(\mathrm{kN})$

$A_{v} \quad=$ Luas penampang tulangan sengkang $\left(\mathrm{mm}^{2}\right)$

$f_{y} \quad=$ Kuat luluh tulangan geser $(\mathrm{MPa})$

$d \quad=$ Tinggi efektif penampang balok beton bertulang ( $\mathrm{mm})$

$s \quad=$ Jarak pusat ke pusat batang tulangan geser kearah sejajar tulangan pokok memanjang $(\mathrm{mm})$

\section{Hasil dan Pembahasan}

\subsection{Respon Beban-Lendutan Balok SCC}

Beban, $\mathrm{P}$ hasil analisis elemen hingga didapatkan dengan prinsip keseimbangan gaya, di mana beban $\mathrm{P}$ adalah penjumlahan dari reaksi gaya arah sumbu $Z$ pada nodal-nodal tumpuan sendi seperti terlihat pada Gambar 7. Perbandingan respon beban-lendutan antara balok beton memadat mandiri hasil eksperimen, SCC-SH-B1 dan SCC-SH-B2, dengan balok beton hasil analisis elemen hingga, SCC-FEM, dapat dilihat pada Gambar 10. Perilaku geser balok SCC hasil analisis elemen hingga ditunjukkan dengan garis tebal hitam. Pada daerah elastik, kurva mengikuti hasil eksperimen balok eksperimen SCC-SH-B2. Setelah terjadi retak pertama balok dimana ditunjukkan dengan perununan beban, $P$, dari $32 \mathrm{kN}$ menjadi $24 \mathrm{kN}$, hasil kurva analisis elemen hingga mengikuti bentuk kurva balok SCC-SH-B1. Untuk kurva hasil analisis elemen hingga pasca retak, kurva mengikuti trend kurva balok SCC-SH-B1. Setelah melewati beban, $P$, sebesar $110 \mathrm{kN}$, hasil kurva elemen hingga berbeda dengan kurva balok SCC-SH-B1.

Berdasarkan Tabel 1, balok eksperimen SCC-SH-B1 menunjukkan beban dan lendutan maksimum sebesar $132,3 \mathrm{kN}$ dan $14,9 \mathrm{~mm}$, berturut-turut. Balok eksperimen SCC-SH-B2 menunjukkan beban dan lendutan maksimum sebesar $107,4 \mathrm{kN}$ dan $8,2 \mathrm{~mm}$, berturut-turut. Pada Gambar 10, terlihat hasil analisis elemen hingga menunjukkan beban dan lendutan maksimum sebesar $145 \mathrm{kN}$ dan $10 \mathrm{~mm}$, berturut-turut.

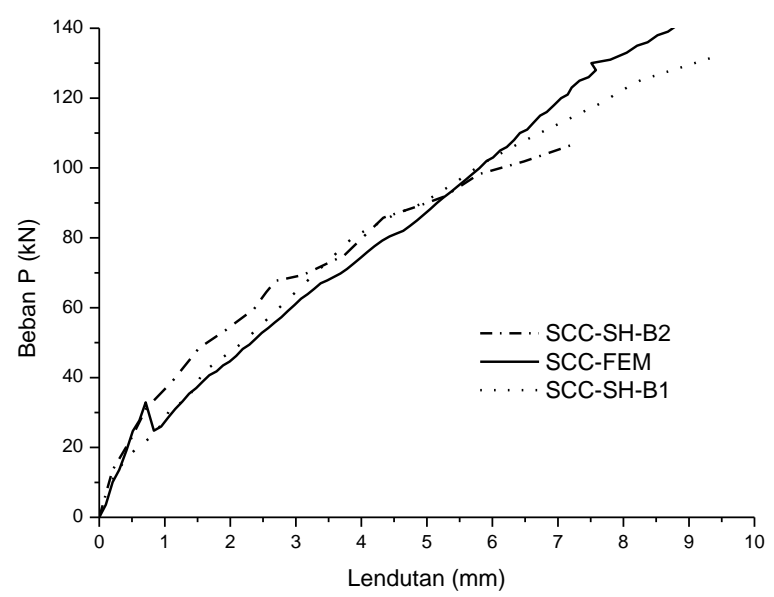

Gambar 10 Kurva beban-lendutan balok geser SCC 
Tabel 3 Beban dan lendutan maksimum (Harkouss and Hamad, 2015)

\begin{tabular}{lcc}
\hline \multicolumn{1}{c}{ Benda Uji } & P maks $(\mathbf{k N})$ & Lendutan Maks, $\Delta_{\text {maks }}(\mathbf{m m})$ \\
\hline SCC-SH-B1 & 132,3 & 14,9 \\
\hline SCC-SH-B2 & 107,4 & 8,2 \\
\hline SCC-FEM & 145 & 10 \\
\hline
\end{tabular}

\subsection{Respon Beban-Lendutan Balok Mutu Tinggi}

Gambar 11 menunjukkan perbandingan respon beban-lendutan antara balok beton mutu tinggi hasil eksperimen, VCC-SH-B1 dan VCC-SH-B2, dengan balok beton tinggi hasil analisis elemen hingga, VCC-FEM, akibat beban geser. Pada daerah elastik kurva beban-lendutan hasil analisis elemen hingga sama dengan hasil eksperimen. Setelah elastik terlampaui maka hasil analisis elemen hingga tren hampir sama dengan hasil eksperimen. Berdasarkan Tabel 2 terlihat bahwa beban maksimum dan lendutan maksimum sebesar $115,5 \mathrm{kN}$ dan $7,8 \mathrm{~mm}$, berturut-turut untuk balok VC-SH-B1. Untuk balok VC-SH-B2 terlihat bahwa beban maksimum dan lendutan maksimum sebesar $127,9 \mathrm{kN}$ dan $11,2 \mathrm{~mm}$, berturut-turut. Pada Gambar 11 terlihat beban maksimum dan lendutan maksimum hasil analisis elemen hingga sebesar $140 \mathrm{kN}$ dan $10 \mathrm{~mm}$, berturut-turut.

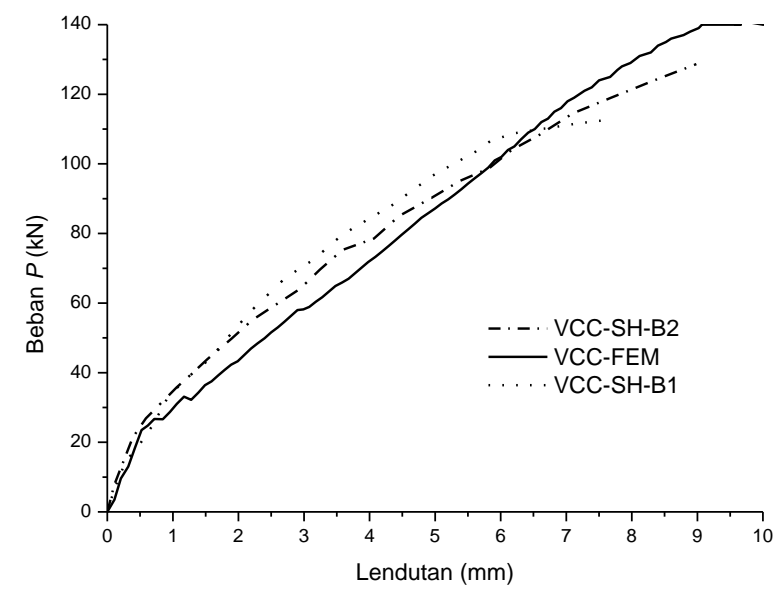

Gambar 11 Kurva beban-lendutan balok geser mutu tinggi

Tabel 4 Beban dan lendutan maksimum (Harkouss and Hamad, 2015)

\begin{tabular}{ccc}
\hline Benda Uji & P maks $(\mathbf{k N})$ & Lendutan Maks, $\Delta_{\text {maks }}(\mathbf{m m})$ \\
\hline VC-SH-B1 & 111,5 & 7,8 \\
\hline VC-SH-B2 & 127,9 & 11,2 \\
\hline VCC-FEM & 140 & 10 \\
\hline
\end{tabular}

\subsection{Pemeriksaan Kekuatan Geser}

Berdasarkan tabel 5, kekuatan geser ulitmit balok memadat mandiri (SCCSH-B1 dan SCC-SH-B2) mempunyai kekuatan sebesar 132,3 kN dan 107,4 kN, berturut-turut. Kekuatan ini lebih besar daripada kekuatan geser balok mutu tinggi (VC-SH-B1 dan VC-SH-B2) yaitu sebesar 111,5 kN dan 127,9 kN, berturut-turut. Hal ini disebabkan karena campuran beton SCC lebih bagus daripada beton VC. Selain itu juga konsistensi konsolidasi diri tinggi beton memiliki pengaruh yang kecil terhadap kapasitas beton dalam geser. 
Kekuatan geser hasil eksperimental dibandingkan dengan estimasi nilai teoritis dari kekuatan beton dan kekuatan geser tulangan hasil perhitungan berdasarkan persamaan (1-3). Hasil dari kegagalan geser balok SCC dan VC mengungkapkan bahwa kapasitas geser ultimit rata-rata yang sama sebesar sekitar $120 \mathrm{kN}$. Kapasitas geser ultimit teoritis nilainya sebesar $93 \mathrm{kN}$ untuk balok SCC dan $91 \mathrm{kN}$ untuk balok VC, berturut-turut.

Hasil percobaan menunjukkan rata-rata kapasitas geser beton $50 \mathrm{kN}$ pada balok SCC dan 42,5 kN pada VC balok dibandingkan dengan beban geser beton teoritis $50 \mathrm{kN}$ untuk balok SCC dan $48 \mathrm{kN}$ untuk balok VC. Faktor reduksi diambil sebesar 0,75 digunakan dalam perhitungan semua kapasitas geser balok teoritis.

Tabel 5 Beban dan lendutan maksimum

\begin{tabular}{ccccc}
\hline Notasi Benda Uji & SCC-SH-B1 & SCC-SH-B2 & VC-SH-B1 & VC-SH-B2 \\
\hline$P$ pada retak pertama $(\mathrm{kN})$ & 50 & 50 & 40 & 45 \\
\hline $\begin{array}{c}P \text { pada kerusakan geser } \\
\text { ultimit }(\mathrm{kN})\end{array}$ & 132,3 & 107,4 & 111,5 & 127,9 \\
\hline $\begin{array}{c}\text { Geser ultimit teoretikal, } \phi V_{n} \\
(\mathrm{kN})\end{array}$ & 93 & 93 & 91 & 91 \\
\hline $\begin{array}{c}\text { kuat geser beton, } \phi V_{c}(\mathrm{kN}) \\
\text { kuat geser tulangan, } \phi V_{c}(\mathrm{kN})\end{array}$ & 50 & 50 & 48 & 48 \\
\hline
\end{tabular}

Kekuatan geser beton teoritis pada persamaan (2) kemudian diverifikasi dengan menggunakan pendekatan model elemen hingga dengan menghilangkan tulang geser dan lentur pada Gambar 8.

Tabel 6 Beban dan lendutan maksimum

\begin{tabular}{ccccc}
\hline Notasi Benda Uji & SCC-SH-B1 & SCC-SH-B2 & VC-SH-B1 & VC-SH-B2 \\
\hline kuat geser beton, $\phi V_{c}(\mathrm{kN})$ & 50 & 50 & 48 & 48 \\
\hline $\begin{array}{c}\text { kuat geser beton hasil } \\
\text { elemen hingga }(\mathrm{kN})\end{array}$ & 49,6 & 49,6 & 44,9 & 44,9 \\
\hline
\end{tabular}

Kurva beban-lendutan balok tanpa tulangan dapat dilihat pada Gambar 12. Pada Gambar 12 terlihat bahwa beban ultimit balok beton memadat mandiri dan beton mutu tinggi tanpa tulangan sebesar $49,6 \mathrm{kN}$ dan $44,9 \mathrm{kN}$, berturut-turut seperti terlihat pada Tabel 6.

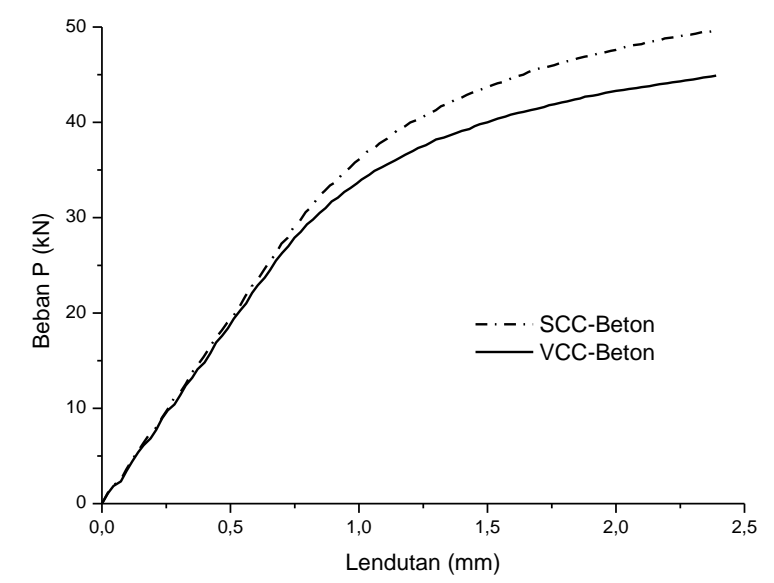

Gambar 12 Kurva beban-lendutan balok tanpa tulangan 


\subsection{Bentuk Balok Analisis}

Gambar 13 menunjukkan hasil akhir balok beton memadat mandiri dengan tulangan lentur dan geser hasil analisis elemen hingga. Garis lurus adalah posisi awal balok sebelum diberi beban. Setelah diberi beban, balok terlihat tidak dalam posisi lurus seperti posisi awal dan melendut ke bawah. Pada daerah tumpuan terlihat bahwa pelat baja dan balok beton bertulang terjadi analisis kontak, hal tersebut terbukti dengan adanya perpisahan nodal antara nodal pelat baja tumpuan dengan nodal balok beton bertulang.

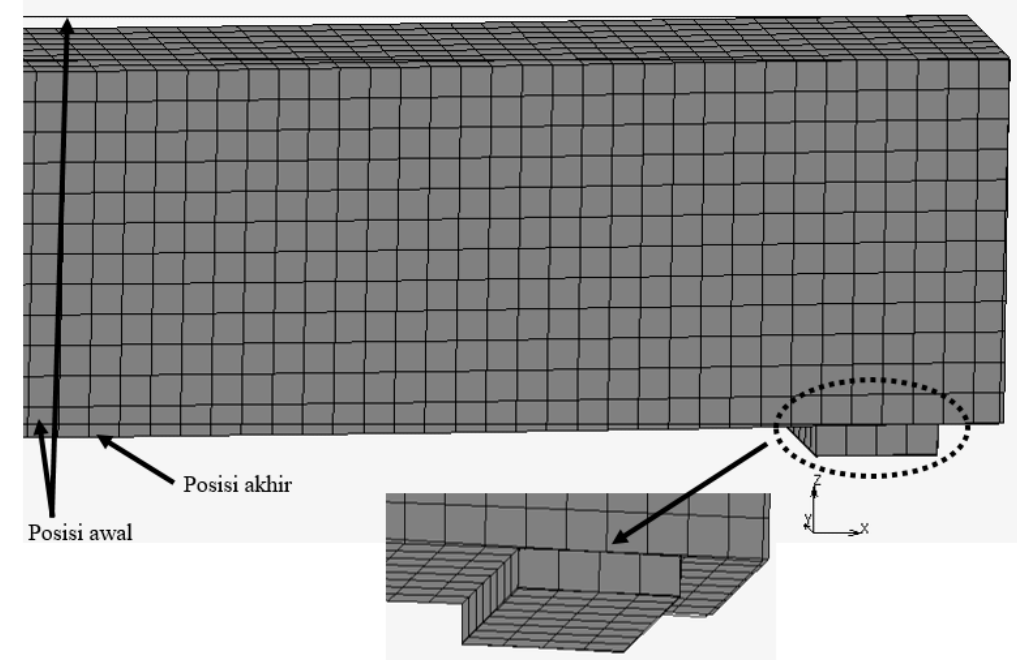

Gambar 13 Bentuk akhir balok analisis elemen hingga

\section{Kesimpulan dan Saran}

\subsection{Kesimpulan}

Pengujian balok beton mutu tinggi dan beton memadat mandiri masingmasing dua buah digunakan sebagai pembanding analisis elemen hingga. Analisis digunakan software MSC Marc/Mentat. Kesimpulan yang dapat diambil bahwa model elemen hingga dengan model tulangan baja pemodelan tertanam/embedded model dapat memodelkan balok eksperimen beton memadat mandiri dan beton mutu tinggi dengan bagus, hal ini dibuktikan dengan hasil kurva beban-lendutan balok beton analisis elemen hingga yang mempunyai tren yang sama dengan kurva balok eksperimen. Pada daerah elastik, kurva mengikuti hasil eksperimen balok beton memadat mandiri SCC-SH-B2. Setelah terjadi retak pertama balok, hasil kurva analisis elemen hingga mengikuti bentuk kurva balok beton memadat mandiri SCC-SH-B1. Pada daerah elastik balok beton mutu tinggi pemadatan mekanis hasil analisis elemen hingga kurva beban-lendutan sama dengan hasil eksperimen. Setelah elastik terlampaui maka hasil analisis elemen hingga tren hampir sama dengan hasil eksperimen. Nilai kekuatan geser hasil eksperimental lebih besar dibandingkan dengan estimasi nilai teoritis dari kekuatan beton dan kekuatan geser tulangan. Kekuatan beton tanpa tulangan hasil teoritis menghasilkan nilai kekuatan yang hampir sama dengan nilai hasil analisis elemen hingga. Hasil analisis elemen hingga menghasilkan bentuk balok beton memadat mandiri dan balok beton mutu tinggi pemadatan mekanis yang tidak lurus lagi. Terjadi perpisahan nodal antara pelat baja tumpuan dan nodal balok. 


\subsection{Saran}

Model elemen hingga pada penelitian ini menggunakan model beton berdasarkan (Kachlakev et al., 2001). Model beton lain perlu untuk diterapkan untuk melihat respon terhadap eksperimen. Berbagai tumpuan juga perlu untuk diteliti untuk melihat efeknya terhadap perilaku struktur balok. Jarak tulangan geser juga perlu untuk diteliti. Jenis tulangan lentur juga perlu dilakukan penelitian.

\section{Ucapan Terima Kasih}

Ucapan terima kasih terutama ditujukan kepada Direktorat Penelitian dan Pengabdian Masyarakat Universitas Islam Indonesia.

\section{Daftar Kepustakaan}

Ahmad, S., Umar, A. and Masood, A, 2017. Properties of normal concrete, selfcompacting concrete and glass fibre-reinforced self-compacting concrete: an experimental study. Procedia engineering. Elsevier, 173, pp. 807-813.

Effendi, M. K, 2020. Study on Non-Linear Flexural Behavior of Reinforced Concrete Beams Using MSC MARC/MENTAT by Embedded Reinforcement Modeling. in Journal of the Civil Engineering Forum.

Harkouss, R. H. and Hamad, B. S, 2015. Performance of high strength selfcompacting concrete beams under different modes of failure. International Journal of Concrete Structures and Materials. Springer, 9(1), pp. 69-88.

Kachlakev, D. I. et al, 2001. Finite element modeling of reinforced concrete structures strengthened with FRP laminates. Oregon. Dept. of Transportation. Research Group.

Marc, M. S. C, 2010. Volume A: Theory and user information. MSC. Software Corporation.

Marc, M. S. C, 2012. Volume B: Element Library, MSC. Software Corporation.

Okamura, H. and Ouchi, M, 2003. Self-compacting concrete. Journal of advanced concrete technology. Japan Concrete Institute, 1(1), pp. 5-15.

Shatarat, N., Mahmoud, H. M. and Katkhuda, H, 2018. Shear capacity investigation of self compacting concrete beams with rectangular spiral reinforcement. Construction and Building Materials. Elsevier, 189, pp. 640-648.

SNI 2847, 2013. SNI 2847-2013 Persyaratan Beton Struktural Untuk Bangunan Gedung. Badan Standardisasi Nasional.

Tambusay, A., Suryanto, B. and Suprobo, P, 2018. Visualization of shear cracks in a reinforced concrete beam using the digital image correlation. International Journal on Advanced Science, Engineering and Information Technology. INSIGHT-Indonesian Society for Knowledge and Human Development, 8(2), pp. 573-578.

Zhou, L., Liu, Z. and He, Z, 2018. Elastic-to-plastic strut-and-tie model for deep beams. Journal of Bridge Engineering. American Society of Civil Engineers, 23(4), p. 4018007. 